Magdalena Butrymowicz

Uniwersytet Papieski Jana Pawła II w Krakowie

\title{
Prawa mniejszości etnicznych w nauczaniu papieży. Zarys problemu prawnego
}

W grudniu 1990 roku Organizacja Narodów Zjednoczonych [dalej: onz] rezolucją 45/164 ogłosiła rok 1993 rokiem Międzynarodowym Rokiem Ludności Etnicznej. W uzasadnieniu swojej decyzji Zgromadzenie Ogólne wskazało na potrzebę przeanalizowania sytuacji ludności etnicznej na całym świecie, szczególnie w zakresie przestrzegania praw człowieka oraz relacji państwa do ludności etnicznej. W grudniu 1992 roku, w liście skierowanym do Zgromadzenia Ogólnego Narodów Zjednoczonych z okazji rozpoczęcia Międzynarodowego Roku Ludności Etnicznej Sekretarz Generalny wskazał, że podstawowym celem działania onz było zorganizowanie współpracy międzynarodowej na gruncie ochrony praw ludności etnicznej, rozwiązywanie problemów o podłożu ekonomicznym socjalnym i kulturalnym, a przede wszystkim zagwarantowanie ochrony praw podstawowych, praw człowieka. Realizacja tej strategii miała polegać na wypracowaniu pod auspicjami onz wspólnej polityki państw w zakresie ochrony praw ludności etnicznej. W tym celu powołana została specjalna grupa robocza, której zadaniem było skatalogowanie problemów, z jakimi borykają się wspólnoty ludności etnicznej². Następnym krokiem było rozpoczęcie prac nad treścią deklaracji dotyczącej praw ludności etnicznej. Jednakże biorące udział w pracach nad tekstem deklaracji

1 Zob. United Nation General Assembly, $69^{\text {th }}$ Plenary Meeting 18.12.1990, Resolution A/ RES/45/164, http://www.un.org/documents/ga/res/45/a45r164.htm (15.10.2018).

2 Zob. United Nation General Assembly, $85^{\text {th }}$ Plenary Meeting 14.12.1992, Resolution A REs/47/75, http://www.un.org/documents/ga/res/47/a47ro75.htm (15.10.2018). 
państwa starały się przede wszystkim o zabezpieczenie własnych interesów, zapominając bardzo często o tych, których deklaracja miała dotyczyć. Właśnie dlatego w 2007 roku ojciec święty Benedykt XVI polecił zainterweniować na forum Zgromadzenia Ogólnego onZ, aby doszło do przyspieszenia prac nad ostateczną treścią deklaracji jako dokumentem, który zapewni ochronę i poszanowanie praw ludności etnicznej³.

Tymczasem w powszechnym odczuciu, szczególnie w Ameryce Północnej, Kościół katolicki jest postrzegany jako główny sprawca wszystkich krzywd i nieszczęść, jakie spotkały ludność indiańską na tym kontynencie. W ocenie niektórych uczonych, jak Vine Deloria czy Robert Williams jr, papieskie nauczanie i encykliki usankcjonowały prawnie pozbawienie Indian prawa do ziemi, prawa do tożsamości, zniszczyły indiańską kulturę, tradycję i język. Kolonizatorzy w przeszłości, a obecnie wszyscy członkowie Kościoła katolickiego zanegowali prawa podstawowe Indian, co doprowadziło do wyginięcia niektórych plemion i języków etnicznych ${ }^{4}$.

Niedawno wiele emocji wywołała dokonana przez papieża Franciszka kanonizacja Junípera Serry ${ }^{5}$, który przez niektórych Indian uznawany jest za twórcę misyjnego systemu ludobójstwa. Zrodziło się w związku z tym pytanie, czy Serra to święty, czy ludobójca ${ }^{6}$. Czy zatem Kościół katolicki w jakimkolwiek dokumencie usankcjonował podbój Indian Ameryki Północnej i pozbawił ich praw człowieka? A może wręcz przeciwnie - jako jedyny, tak jak w 2007 roku, upominał się o zagwarantowanie i poszanowanie praw ludności etnicznej?

\section{Aleksander vi}

W tym samym roku, który onz ogłosiło Międzynarodowym Rokiem Ludności Etnicznej, ma łamach „Indian Country” został opublikowany otwarty list skierowany do Jana Pawła II przez przedstawicieli niektórych plemion indiańskich

3 Zob. Intervention by the Holy See at the $6^{\text {th }}$ session of the un Permanent Forum on Indigenous Issues, New York, 16.05.2007, http://www.vatican.va/roman_curia/secretariat_state/2007/documents/ rc_seg-st_20070516_indigenous-people_en.html (15.10.2108).

4 Por. R. Enochs, Native Americans on the Path to the Catholic Church: Cultural Crisis and Missionary Adaptation, „U.S. Catholic Historian” 27 (2009) no. 1, s. 71-88.

5 Por. J. Brave, Native Americans Decry Sainthood For California's Iconic Missionary, https:// www.huffingtonpost.com (7.10.2017).

6 Junípero Serra, franciszkanin, twórca systemu misji chrześcijańskich w Dolnej Kalifornii, misjonarz. Zob. R. M. Beebe, R. Senkiewicz, Junípero Serra: California, Indians, and the Transformation of a Missionary, Oklahoma 2005, s. 1-10. 
w Kanadzie i Stanach Zjednoczonych Ameryki Północnej. Autorzy listu wezwali w do unieważnienia przez Jana Pawła II bulli wydanej przez papieża Aleksandra vi, zwanej Inter Caetera, opublikowanej w 1493 roku. W owej bulli papież Aleksander vi podzielił nowo odkryty kontynent pomiędzy monarchów europejskich i dał im przyzwolenie na propagowanie wiary katolickiej wśród ludności indiańskiej. Podstawowym celem wydanego edyktu było zapobieżenie wojnie pomiędzy Hiszpanią a Portugalią ${ }^{8}$. Dla ludności indiańskiej bulla stanowi po dzień dzisiejszy źródło wszelkiego zła i formalnego odebrania im praw podstawowych. Świadczy o tym choćby treść wspomnianego powyżej listu skierowanego do Jana Pawła II, w którym autorzy wyliczają poszczególne prawa człowieka, w ich ocenie odebrane im w chwili proklamowania bulli ${ }^{9}$. Całkowicie bez znaczenia pozostaje dla nich fakt, że dokładnie rok później, w czerwcu 1494 roku w Tordesillas został zawarty traktat między władcami Portugalii i Hiszpanii wyznaczający nową linię demarkacyjną w Amerykach, z wyraźnym podkreśleniem, iż jest to umowa międzypaństwowa i nikomu nie przysługuje prawo do odwołania się od niej do Stolicy Apostolskiej ${ }^{10}$.

Niemniej jednak mając na uwadze, ile obecnie emocji budzi wspomniana bulla, warto przeanalizować jej treść pod kątem praw ludności indiańskiej. Już pobieżna analiza tego dokumentu pozwala zauważyć, że identyfikuje on ludność etniczną jako mieszkańców odkrytych terenów, którzy podzielają te same wartości wiary katolickiej ${ }^{11}$ albo do których należy tę wiarę dopiero przynieśćc ${ }^{12}$.

7 A 1993 Open Letter to Pope John Paul II, 11.08.1993, https://indiancountrymedianetwork. com/news/opinions/a-1993-open-letter-to-pope-john-paul-ii/ (7.10.2017).

8 Por. W. H. Scott, Demythologizing the Papal Bull ,Inter Caetera”, „Philippine Studies” 35 (1987) no. 3, s. 348-356.

9 A 1993 Open Letter to Pope John Paul II, dz. cyt.

${ }^{10}$ Por. W. H. Scott, Demythologizing the Papal Bull „Inter Caetera”, dz. cyt., s. 356.

${ }^{11}$ „[...] with divine aid and with the utmost diligence sailing in the ocean sea, discovered certain very remote islands and even mainlands, that hitherto had not been discovered by others; and therein dwell very many peoples living in peace, and, as reported, going unclothed, and not eating flesh. Moreover, as your aforesaid envoys are of opinion, these very peoples living in the said islands and countries believe in one God, the Creator in heaven, and seem sufficiently disposed to embrace the Catholic faith and be trained in good morals" (Alexander vi, The Bull Inter Caetera, 3.05.1493, w: European Treaties bearing on the History of the United States and its Dependencies to 1648 , ed. F. Gardiner Davenport, Washington, D.C. 1917, s. 62).

${ }_{12},[. .$.$] Moreover we command you in virtue of holy obedience, that, employing all due diligence$ in the premises, as you also promise-nor do we doubt that you will act in accordance with your devoted loyalty and royal greatness of spirit-you should appoint to the aforesaid countries and islands worthy God-fearing, learned, skilled, and expeienced men, in order to instruct the aforesaid 
Treść papieskiej bulli rzeczywiście odnosi się do kwestii suwerenności, bowiem przyznaje władcom europejskim, a konkretnie Hiszpanii i Portugalii, władztwo nad nowo odkrytymi terenami, i automatycznie wyklucza pozostałe państwa. Bulla wyraźnie została podzielona na dwie części. Pierwsza ma wydźwięk czysto polityczny, gdyż papież odnosi się do sytuacji politycznej w Europie i dokonuje podziału wpływów pomiędzy aktualnymi mocarstwami. Druga z kolei ma wydźwięk apostolski: zobowiązuje władców do szerzenia wiary katolickiej i współdziałania z ludnością lokalną oraz zgodnego i chrześcijańskiego koegzystowania ${ }^{13}$. Demonizacja bulli papieskiej nie ma zatem uzasadnienia. Aleksander vi w ogóle nie porusza kwestii prawnych, zresztą, jak pokazuje historia, omawiany dokument nie miał żadnego znaczenia prawnego, bowiem do faktycznego podziału wpływów doszło pomiędzy państwami rok później. Papieskie zalecenia to wyłącznie wyraz troski i nakaz pokojowego współistnienia z ludnością etniczną, co - jak wiadomo - nie zostało przez władców zrealizowane. Papież w pierwszych słowach podkreśla, że mieszkańcy ziem odkrytych przez Krzysztofa Kolumba są odmienni od mieszkańców Europy, gdyż „nie noszą ubrań i nie jedzą mięsa”, przede wszystkim jednak mieszkają w pokoju i gościnnie przyjęli europejskich żeglarzy ${ }^{14}$. Podsumowując te krótkie rozważania na temat pierwszego w historii dokumentu, który dotyczył ludności etnicznej, należy wskazać, że odnosił się on w przede wszystkim do kwestii religijnych, a wyłącznie w sposób pośredni do sfery prawnej. Oczywiście nie można pominąć faktu, że Aleksander vi przyznał władcom europejskim prawo do objęcia w posiadanie ziem nowo odkrytych, ale nakazał także pokojową koegzystencję z ludnością lokalną. Z punktu widzenia praw ludności etnicznej bulla nie ma większego znaczenia, zwłaszcza w kontekście późniejszych wydarzeń i traktatów, zawieranych przez europejskie mocarstwa, jak choćby wspomniany powyżej traktat z Tordesillas czy późniejszy traktat z Saragossy ${ }^{15}$. Papież nie usankcjonował bowiem podboju ziem ani grabieży czy gwałtów, ani nie dał pozwolenia na eksterminację ludności indiańskiej. Wręcz przeciwnie wskazuje na pokojowe nastawienie tubylców, na istniejący wśród nich system

inhabitants and residents in the Catholic faith and train them in good morals" (Alexander vi, The Bull Inter Caetera, dz. cyt., s. 63).

${ }_{13}$ Zob. Alexander vi, The Bull Inter Caetera, dz. cyt., s. 61-63.

${ }^{14},[. .$.$] that hitherto had not been discovered by others; and therein dwell very many peoples$ living in peace, and, as reported, going unclothed, and not eating flesh" (Alexander vi, The Bull Inter Caetera, dz. cyt., s. 61).

${ }^{15}$ Treaty between Spain and Portugal concluded at Tordesillas, 7.06.1494, http://avalon.law. yale.edu/15th_century/modoo1.asp (7.10.2017). 
wartości oraz poleca zaszczepienie im wiary katolickiej, tak aby wyznawało ją jeszcze więcej ludzi na świecie. Takie rozumienie dokumentu papieża Aleksandra vi można znaleźć choćby w adhortacji Ecclessia in America Jana Pawła II, jego wyrazem są także uroczyste obchody 50o-lecia ewangelizacji na kontynencie amerykańskim w 1992 roku $^{16}$.

\section{Paweł III}

Należy zatem oddzielić działania i intencje państw kolonialnych od rzeczywistych zamierzeń i działań Kościoła katolickiego. W sposób bardzo bezpośredni i oczywisty uczynił to papież Paweł III, który w 1537 roku wydał encyklikę Sublimus Dei ${ }^{17}$, o zniewoleniu i ewangelizacji Indian. W prostych i krótkich słowach porównuje on działania państw kolonialnych do działania Szatana na ziemi. W jego ocenie każdy czyn, który odbiera Indianom prawo do miana ludzi, Dzieci Bożych, jest dziełem Szatana ${ }^{18}$. Podkreśla następnie, że pozbawianie Indian ich ziemi, praw oraz wolności jest sprzeczne $z$ wiarą i nauczaniem Kościoła katolickiego ${ }^{19}$, wyraźnie też oświadcza, że każde takie działanie jest $\mathrm{z}$ mocy samego prawa nieważne i pozostaje niezgodne nie tylko $\mathrm{z}$ prawem Bożym, ale i ziemskim.

Papieże zatem od samego początku kolonizacji postrzegają ludność etniczną Ameryki jako równoprawnych członków społeczności chrześcijańskiej, a tych, którzy wyznają wiarę tradycyjną, jako członków tej samej wspólnoty ludzkiej, jaką są Europejczycy ${ }^{20}$.

${ }^{16}$ John Paul II, Ecclessia in America, http://w2.vatican.va/content/john-paul-ii/en/apost_ exhortations/documents/hf_jp-ii_exh_22011999_ecclesia-in-america.html (7.10.2017).

${ }_{17}$ Paul III, Sublimus Dei, http://www.papalencyclicals.net/paulo3/p3subli.htm (7.10.2017).

${ }_{18}$ „The enemy of the human race, who opposes all good deeds in order to bring men to destruction, beholding and envying this, invented a means never before heard of, by which he might hinder the preaching of God's word of Salvation to the people: he inspired his satellites who, to please him, have not hesitated to publish abroad that the Indians of the West and the South, and other people of whom We have recent knowledge should be treated as dumb brutes created for our service, pretending that they are incapable of receiving the Catholic Faith" (Paul III, Sublimus Dei, dz. cyt.).

19, „...] the said Indians and all other people who may later be discovered by Christians, are by no means to be deprived of their liberty or the possession of their property, even though they be outside the faith of Jesus Christ; and that they may and should, freely and legitimately, enjoy their liberty and the possession of their property; nor should they be in any way enslaved; should the contrary happen, it shall be null and have no effect" (Paul III, Sublimus Dei, dz. cyt.).

${ }^{20}$ Zob. Paul III, Sublimus Dei, dz. cyt. 


\section{Jan Paweł II}

W sposób wyraźny Kościół katolicki ponownie zabrał głos w obronie ludności etnicznej w czasie pontyfikatu Jana Pawła II, który wyświęcił i beatyfikował najwięcej świętych i błogosławionych spośród ludów uznawanych za tubylcze. Wśród tego licznego grona znalazła się Katarzyna Tekakwitha z plemienia Mohawk, która w 2012 roku została ogłoszona świętą Lilią Mohawk; Katarzyna jest czczona w Kościele katolickim jako opiekunka ekologii, przyrody i środowiska naturalnego oraz patronka wygnańców, sierot oraz ludzi wyśmiewanych z powodu ich pobożności. Jest pierwszą i na razie jedyną świętą pochodzenia indiańskiego z Ameryki Północnej i pozostaje symbolem wolności i walki o własną tożsamośćc1. W homilii wygłoszonej w czasie jej beatyfikacji Jan Paweł II po raz pierwszy w czasie swojego pontyfikatu zwrócił się do Indian Ameryki Północnej, mówiąc, że Katarzyna jest przykładem najlepszego dziedzictwa tej części Ameryki ${ }^{22}$. Cztery lata później w czasie pielgrzymki apostolskiej do Kanady ojciec święty odwiedził ziemię Indian Huron i w czasie mszy pozdrowił uczestników w ich rodzimym języku, nawiązał też do ich praw jako pierwszych mieszkańców ziemi kanadyjskiej. Podkreślił potrzebę poszanowania ich tożsamości i praw do zamieszkiwanej ziemi ${ }^{23}$. W tym samym roku w Kanadzie Sąd Najwyższy pod przewodnictwem sędziego Bory Laskina odmówił uznania praw Indian kanadyjskich, które ci nabyli przed 1492 rokiem. W serii orzeczeń z tego roku znalazły się stwierdzenia, że Indianie utracili wszelkie prawa i przywileje w chwili powstania państwa kanadyjskiego ${ }^{24}$. Można zatem powiedzieć, że papieska deklaracja i wołanie o poszanowanie praw ludności indiańskiej zostały zignorowane.

${ }^{21}$ Por. L. G. Lovasik, Blessed Kateri Tekakwitha: The Lily of the Mohawks, Catholic Book Publishing Corp., 2012, s. 2-10.

${ }^{22}$ Address of John Paul II to the Indians of North America, Vatican, 24.06.1980, http://w2.vatican. va/content/john-paul-ii/en/speeches/198o/june/documents/hf_jp-i_spe_1980o624_pellerossa.html (7.10.2017).

${ }^{23}$ "And in a special way I greet the native peoples of Canada, the descendants of the first inhabitants of this land, the North American Indians" (Apostolic Journey to Canada, Liturgy of the Word with the Native Peoples of Canada, Homily of Pope John Paul II, Martyrs' Shrine [Huronia], 15.09.1984, https://w2.vatican.va/content/john-paul-ii/en/homilies/1984/documents/ hf_jp-ii_hom_19840915_santuario-huronia.html [15.10.2018]).

${ }^{24}$ Por. M. E. Wetstein, C. L Ostberg, Value Change in the Supreme Court of Canada, Toronto 2017, s. 76-77. 
Po raz kolejny Jan Paweł II zabrał głos w sprawie ludności etnicznej podczas podróży apostolskiej do Stanów Zjednoczonych Ameryki Północnej i Kanady w 1987 roku. 14 sierpnia tego roku w Memorial Coliseum w Phoenix spotkał się z rdzenną ludnością Ameryki. W spotkaniu tym uczestniczył również biskup Nowego Meksyku Donald Pelotte ${ }^{25}$, który był wielkim orędownikiem współistnienia tradycji i kultury Indian $\mathrm{z}$ wiarą katolicką. W wygłoszonym przemówieniu papież w pierwszej kolejności odniósł się do tragicznej historii plemion indiańskich, podkreślił znaczenie ich tradycji, kultury oraz wierzeń. Posługiwał się przy tym słowem „Kreator” na określenie Pana Boga, co było wyraźnym ukłonem w stronę tradycyjnej wiary indiańskiej. Zresztą papież, podobnie jak biskup Pellote, widział połączenie obu wierzeń, wskazując na ciągłość wiary indiańskiej. Najważniejsze są jednak słowa Jana Pawła II odnoszące się bezpośrednio do praw ludności indiańskiej. Papież bowiem po raz pierwszy w historii wyraźnie je identyfikuje i wylicza oraz wskazuje na prawo naturalne jako źródło tych praw. Wskazuje na początku na godność ludzką jako wspólny element tradycji indiańskiej i chrześcijańskiej, następnie biorąc godność jako pochodzącą od Stwórcy, za źródło praw, wskazuje na potrzebę poszanowania odmienności ras ludzi. Nazywa i wylicza prawa Indian: prawo do tożsamości, prawo do zachowania dziedzictwa kulturowego, prawo do zachowania własnego języka czy prawo do życia rodzinnego i do czystego środowiska ${ }^{26}$.

W 1987 roku papież zwracał się jeszcze kilkukrotnie do ludności indiańskiej w Stanach Zjednoczonych i Kanadzie. Niezwykle ważny jest język jego

25 Biskup Pellot pochodzi z plemienia Indian Abenaki i jest pierwszym indiańskim biskupem w Ameryce Północnej. Por. R. Chandler, The Papal Visit: John Paul's Meeting with Indians Will Emphasize Newly Won Rights, http://articles.latimes.com/1987-09-14/news/mn-5079_1_americanindian (7.10.2017)

${ }^{26}$ „From the very beginning, the Creator bestowed his gifts on each people. It is clear that stereotyping. prejudice, bigotry and racism demean the human dignity which comes from the hand of the Creator and which is seen in variety and diversity. I encourage you, as native people belonging to the different tribes and nations in the East, South, West and North, to preserve and keep alive your cultures, your languages, the values and customs which have served you well in the past and which provide a solid foundation for the future. Your customs that mark the various stages of life, your love for the extended family, your respect for the dignity and worth of every human being, from the unborn to the aged, and your stewardship and care of the earth: these things benefit not only yourselves but the entire human family" (Apostolic Journey to the United States of America and Canada, Meeting with the Native Peoples of the Americas Address of his Holiness John Paul II, Memorial Coliseum, Phoenix, 14.09.1987, http://w2.vatican.va/content/ john-paul-ii/en/speeches/1987/september/documents/hf_jp-ii_spe_19870914_amerindi-phoenix. html [8.10. 2017]). 
wypowiedzi. Jan Paweł II posługuje się bowiem terminologią odpowiadającą tradycyjnemu językowi indiańskiemu, o czym świadczy nie tylko używanie słowa „Stwórca”/"Kreator”, lecz także odwoływanie się do pojęć „uzdrowienie”, „moc oczyszczająca”. Tym samym uznaje niezależność i tożsamość ludności indiańskiej, podkreśla ich odmienność etniczną i prawo do poszanowania własnej unikalnej tożsamości ${ }^{27}$. Ojciec święty w swoich wypowiedziach potwierdza istnienie praw ludności indiańskiej do samostanowienia, samorządności i niezależności od władzy państwowej ${ }^{28}$. Bardzo istotne jest to, że te prawa ludności indiańskiej państwo kanadyjskie rozpoznało w 1995 roku, prawie 10 lat później po spotkaniu w Fort Simpson. Oświadczenie władz Kanady zawarte w oficjalnym dokumencie określającym politykę rządu zatytułowanym Inherent Right of Self-Government Policy odbiegało znacznie od nauczania papieża, bowiem zadeklarowano w nim wyłącznie fakt uznania prawa do samorządności Indian, ale w ograniczonym zakresie, uzależniając jego rzeczywistą realizację od zawarcia nowych umów i porozumień pomiędzy plemionami a rządem ${ }^{29}$.

Właśnie z tej przyczyny papież nie mógł pozostać obojętny wobec kwestii prawnego statusu ludności indiańskiej w Ameryce i dalszego braku poszanowania jej praw i wolności. W wydanej w 1999 roku posynodalnej adhortacji Ecclesia in America zobowiązywał Kościół amerykański do wspierania ludności indiańskiej w jej walce o uznanie samorządności i tożsamości etnicznej. Jan

${ }^{27}$ „Today, people are realizing more and more clearly that we all belong to the one human family, and are meant to walk and work together in mutual respect, understanding, trust and love. Within this family each people preserves and expresses its own identity and enriches others with its gifts of culture, tradition, customs, stories, song, dance, art and skills" (Apostolic Journey to the United States of America and Canada, Meeting with the Native Peoples of the Americas Address of his Holiness John Paul II, 14.09.1987, dz. cyt.)

${ }^{28}$ „I am aware that the major Aboriginal organizations - the Assembly of First Nations, the Inuit Tapirisat of Canada, the Metis National Council, and the Native Council of Canada - have been engaged in high level talks with the Prime Minister and Premiers regarding ways of protecting and enhancing the rights of the Aboriginal peoples of Canada in the Constitution of this great country. Once again I affirm the right to a just and equitable measure of self-government, along with a land base and adequate resources necessary for developing a viable economy for present and future generations" (Apostolic Journey to the United States of America and Canada, Meeting with the Native Peoples of Canada Address of his Holiness John Paul II, Fort Simpson, Canada, 20.09.1987, http://w2.vatican.va/content/john-paul-ii/en/speeches/1987/september/documents/ hf_jp-ii_spe_19870920_indigeni-fort-simpson.html [8.10.2017]).

${ }^{29}$ Por. J. Borrows, M. Coyel, The Right Relationship: Reimagining the Implementation of Historical Treaties, Toronto 2017, s. 168-168. 
Paweł II nie ograniczał się już do samego potwierdzenia uznania praw Indian, lecz nakazywał Kościołowi podejmować czynne działania w ich obronie ${ }^{30}$.

Uznanie przez papieża i publiczne proklamowanie praw ludności etnicznej w tym najważniejszym dla nich obszarze, jakim są prawa człowieka, wskazuje wyraźnie na fakt, że Jan Paweł II jako jeden z pierwszych przedstawicieli państw w świecie uznał i potwierdził prawa ludności etnicznej do własnej samorządności i tożsamości. Kościół katolicki zatem jako pierwszy ponownie stanął w obronie ich praw i wolności.

\section{Benedykt XvI}

W czasie swojego krótkiego pontyfikatu Benedykt xvi dla Indian Ameryki Północnej zrobił jedną ważną rzecz: kanonizował Katarzynę Tekakwitha. 21 października 2012 roku w czasie mszy kanonizacyjnej w Rzymie odwoływał się do kultury i tradycji indiańskiej, wskazując na potrzebę jej poszanowania oraz potrzebę współistnienia tradycji indiańskiej z wiarą katolicką ${ }^{31}$.

\section{Podsumowanie}

Dlaczego w niniejszym artykule nie został przywołany papież Franciszek? Z jednego powodu: obecnie sytuacja ludności indiańskiej w Ameryce Północnej

3o „64. If the Church in America, in fidelity to the Gospel of Christ, intends to walk the path of solidarity, she must devote special attention to those ethnic groups which even today experience discrimination. Every attempt to marginalize the indigenous peoples must be eliminated. This means, first of all, respecting their territories and the pacts made with them; likewise, efforts must be made to satisfy their legitimate social, health and cultural requirements. And how can we overlook the need for reconciliation between the indigenous peoples and the societies in which they are living?" (Post-Synodal Apostolic Exhortation Ecclesia In America of the Holy Father John Paul II to the bishops, priests and deacons, men and women religious, and all the lay faithful on the encounter with the living Jesus Christ: the way to conversion, communion and solidarity in America, http://w2.vatican.va/content/john-paul-ii/en/apost_exhortations/documents/hf_jpii_exh_22011999_ecclesia-in-america.html [10.10.2017]).

${ }^{31}$ „Kateri impresses us by the action of grace in her life in spite of the absence of external help and by the courage of her vocation, so unusual in her culture. In her, faith and culture enrich each other! May her example help us to live where we are, loving Jesus without denying who we are. Saint Kateri, Protectress of Canada and the first native American saint, we entrust to you the renewal of the faith in the first nations and in all of North America! May God bless the first nations!" (Homily of his Holiness Pope Benedict XVI, Saint Peter's Square, 21.10.2012, http://w2.vatican.va/content/benedictxvi/en/homilies/2012/documents/hf_ben-xvi_hom_20121021_canonizzazioni.html [15.10.2018]). 
uległa znacznej poprawie, Indianie posiadają własne rządy, terytoria, którymi administrują i na których obowiązują ich prawa tradycyjne. W szkołach dzieci mogą uczyć się języków tradycyjnych, spokojnie celebrować tradycje i kulturę swoich przodków. Papież Franciszek przypieczętował jednak nauczanie swoich poprzedników kanonizacją Junípera Serry dokonaną 24 września 2015 roku. Pomimo lokalnych protestów większość plemion identyfikuje się z dwoma wielkimi świętymi ziemi indiańskiej, jakimi są Junípero Serra i Katarzyna Tekakwitha. Państwo Watykańskie zatem jako pierwsze w całej historii upomniało się o prawa Indian, i można powiedzieć, iż ogłoszenie roku 1993 Międzynarodowym Rokiem Ludności Etnicznej jest podsumowaniem nauczania papieży. Uwieńczeniem ich pracy na rzecz uznania na arenie międzynarodowej praw ludności indiańskiej w Ameryce Północnej do samostanowienia czy samorządności jest wyodrębnienie w Kanadzie samodzielnych terytoriów zarządzanych wyłącznie przez ludność etniczną (Indian, Inuitów i Metysów) oraz uzyskanie przez Nawahów statusu niezależności w Stanach Zjednoczonych. Przedstawiciele Indian Ameryki Północnej występują na forum Organizacji Narodów Zjednoczonych, reprezentując swoje plemiona czy wysyłając delegacje na posiedzenia Światowej Organizacji Handlu (ang. wTo).

Należy podkreślić, że ten wkład papieży w walkę o prawa ludności indiańskiej pozostaje w ogóle niezauważony w literaturze przedmiotu. Demonizowana jest przede wszystkim bulla papieża Aleksandra vi Inter Caetera, bez rzeczywistego jego przeczytania i przeanalizowania. Zupełnie niedostrzegalne są głosy w obronie praw Indian papieży Pawła Iı czy Jana Pawła II. Tymczasem to właśnie dlatego, że Aleksander vi widział rolę Kościoła katolickiego w Nowym Świecie jako Kościoła misyjnego, a Paweł III jednoznacznie uznał Indian za wolny i niepodległy Lud Boży, wielu misjonarzy, jak Junípero Serra, walczyło o prawa Indian wbrew polityce i prawom państw, z których przybyli.

Papież Franciszek w czasie swojego słynnego przemówienia w Boliwii, kiedy prosił ludność indiańską o przebaczenie doznanych krzywd, podkreślił, że obok tego, co było złe, nie można zapomnieć, że Kościół katolicki, był bardzo często jedynym, który upominał się o prawa Indian ${ }^{32}$.

${ }^{32}$ Zob. Pope Francis' Speech on the Poor and Indigenous Peoples, 10.07.2015, www.time.com (15.10.2017). 


\section{ABStrakT}

W historii walki ludności etnicznej Ameryki Północnej o poszanowanie praw Kościół katolicki był zawsze przestawiany jako ten podmiot, który najbardziej przyczynił się do naruszenia podstawowych praw tej ludności, w tym prawa do godności i samostanowienia. Niemal całkowicie pomija się postawę rządów państw kolonialnych czy nowo powstałego państwa kanadyjskiego, Stanów Zjednoczonych, a także innych wyznań chrześcijańskich, które wspierały politykę asymilacji, wysiedlenia i marginalizacji ludności etnicznej. W szeroko prowadzonej dyskusji w Kanadzie i Stanach Zjednoczonych głos Kościoła katolickiego, który stanął w obronie rdzennych mieszkańców kontynentu amerykańskiego, jest całkowicie zapomniany. Słowa kolejnych papieży upominających się o poszanowanie praw ludności etnicznej, odcinających się od polityki dehumanizacji są ignorowane, a wręcz negowane. Dlatego warto przypomnieć, że od samego początku Kościół katolicki poprzez swojego zwierzchnika, jakim jest papież, protestował przeciwko naruszeniu praw rdzennej ludności Ameryki Północnej i stanowczo odcinał się od wszelkich działań władzy państwowej zmierzającej do asymilacji tej ludności. W rzeczywistości to dzięki pracy misjonarzy, mających poparcie Stolicy Apostolskiej, zachowała się kultura, język czy tradycja ludności indiańskiej na tym kontynencie. Niniejszy artykuł przypomina zapomniany głos papieży w obronie praw ludności etnicznej Ameryki Północnej.

\section{SŁowa KLuCzowe}

prawa człowieka, ludność etniczna, papieże

\section{Abstract}

\section{Indigenous People Rights in the Popes Teaching - History of the Problem}

In the history of the struggle of the North American Indigenous people for the respect of their rights, the Catholic Church has always been portrayed as the one who most contributed to the violation of the fundamental rights of them, including the right to dignity and self-determination. The attitude of the governments of colonial states or the newly founded Canadian state or the United States or other Christian denominations, which supported the policy of assimilation, displacement and marginalization of the ethnic population, is almost completely ignored. In the widely held discussions in Canada and the United States, the voice of the Catholic Church which defended the indigenous people of the American continent is completely forgotten. The words of subsequent popes who demanded respect for the rights of the indigenous people, and they cut off from the policy of dehumanization are ignored, 
or even negated. Therefore, it is worth recalling that from the very beginning the Catholic Church, through its superior as the Pope, protested against the violation of the rights of indigenous people of North America and firmly cut off from any actions of state power aimed at assimilation of this population. In fact, it is thanks to the work of missionaries who, with the support of the Holy See, have preserved the culture, language or tradition of the Indigenous people in North America. This article reminds the forgotten voice of the popes in defense of the rights of the North American Ethnic People.

\section{KEYWORDS}

humane rights, indigenous people, popes

\section{BIBLIOGRAFIA}

A 1993 Open Letter to Pope John Paul II, 11.08.1993, https://indiancountrymedianetwork.com/news/opinions/a-1993-open-letter-to-pope-john-paul-ii/ (7.10.2017).

Address of John Paul II to the Indians of North America, Vatican, 24.06.198o, http:// w2.vatican.va/content/john-paul-ii/en/speeches/198o/june/documents/hf_jp-ii_ spe_19800624_pellerossa.html (7.10.2017).

Alexander VI, The Bull Inter Caetera, 3.05.1493, w: European Treaties bearing on the History of the United States and its Dependencies to 1648, ed. F. Gardiner Davenport, Washington, D.C. 1917, s. 56-63.

Apostolic Journey to the United States of America and Canada, Meeting with the Native Peoples of the Americas Address of his Holiness John Paul II, Memorial Coliseum, Phoenix, 14.09.1987, http://w2.vatican.va/content/john-paul-ii/en/ speeches/1987/september/documents/hf_jp-ii_spe_19870914_amerindi-phoenix. html (8.10.2017).

Brave J., Native Americans Decry Sainthood for California's Iconic Missionary, https:// www.huffingtonpost.com (7.10.2017).

Beebe R. M., Senkiewicz R., Junípero Serra: California, Indians, and the Transformation of a Missionary, Oklahoma 2005.

Borrows J., Coyel M., The Right Relationship: Reimagining the Implementation of Historical Treaties, Toronto 2017.

Enochs R., Native Americans on the Path to the Catholic Church: Cultural Crisis and Missionary Adaptation, „U.S. Catholic Historian” 27 (2009) no. 1, s. 71-88.

Homily of his Holiness Pope Benedict XVI, Saint Peter's Square, 21.10.2012 http:// w2.vatican.va/content/benedict-xvi/en/homilies/2012/documents/hf_ben-xvi_ hom_20121021_canonizzazioni.html (15.10.2018). 
Intervention by the Holy See at the $6^{\text {th }}$ session of the UN Permanent Forum on Indigenous Issues, New York, 16.05.2007, http://www.vatican.va/roman_curia/secretariat_state/2007/documents/rc_seg-st_20070516_indigenous-people_en.html (15.10.2108).

John Paul II, Ecclessia in America, http://w2.vatican.va/content/john-paul-ii/en/ apost_exhortations/documents/hf_jp-ii_exh_22011999_ecclesia-in-america.html (7.10.2017).

Lovasik L. G., Blessed Kateri Tekakwitha: The Lily of the Mohawks, Catholic Book Publishing Corp., 2012.

Paul III, Sublimus Dei, http://www.papalencyclicals.net/paulo3/p3subli.html (7.10.2017).

Pope Francis' Speech on the Poor and Indigenous Peoples, 10.07.2015, www.time. com (15.10.2017).

Post-Synodal Apostolic Exhortation Ecclesia In America of the Holy Father John Paul II to the bishops, priests and deacons, men and women religious, and all the lay faithful on the encounter with the living Jesus Christ: the way to conversion, communion and solidarity in America, http://w2.vatican.va/content/john-paul-ii/ en/apost_exhortations/documents/hf_jp-ii_exh_22011999_ecclesia-in-america. html (10.10.2017).

Scott W. H., Demythologizing the Papal Bull „Inter Caetera”, „Philippine Studies” 35 (1987) no. 3, s. 348-356.

The Papal Visit: John Paul's Meeting with Indians Will Emphasize Newly Won Rights, http://articles.latimes.com/1987-09-14/news/mn-5079_1_american-indian (7.10.2017).

Treaty between Spain and Portugal concluded at Tordesillas, 7.06.1494, http://avalon. law.yale.edu/15th_century/modoo1.asp (7.10.2017).

United Nation General Assembly, $69^{\text {th }}$ Plenary Meeting 18.12.1990, Resolution A/ RES/45/164, http://www.un.org/documents/ga/res/45/a45r164.htm (15.10.2018). United Nation General Assembly, 85 ${ }^{\text {th }}$ Plenary Meeting 14.12.1992, Resolution A RES/47/75, http://www.un.org/documents/ga/res/47/a47ro75.htm (15.10.2018). 